\title{
Potability of Ground Water from Areas around a Cane- Sugar Industry: A Case Study
}

\author{
Akanksha Haribhau Kawade and Priyanka K. Gadhave
}

\begin{abstract}
Water pollution due to industrial activities is a major concern for environmentalists. The effluents produced from cane sugar industries are highly toxic and if let out untreated can cause serious water quality degradation. The aim of the present study is to evaluate the effects of cane sugar industry on its nearby ground water quality. The study includes analysis of eight water samples from tube-wells near to the factory for water quality parameters such as $\mathrm{pH}$, DO, BOD, COD, total dissolved solids, $\mathrm{Ca}, \mathrm{Mg}, \mathrm{Na}, \mathrm{Zn}, \mathrm{K}, \mathrm{Cl}$, and Fe. As many parameters showed substantive deviation from their prescribed normal values, the results of the study show that the ground water has been significantly affected and is not at all potable. The remedial measures to curb this deterioration are also discussed.
\end{abstract}

Index Terms - Water quality, cane sugar industry, tube-well, potability, remedial measures.

\section{INTRODUCTION}

Water is very important life supporting material and required for all organism for the life processes. Water is needed not only for domestic usage and irrigation but also for sanitation and waste disposal. Water in nature is never pure in chemical sense. The impurities present in water naturally are meagre, but due to rapid industrialization, over population, indiscriminate use of chemicals increases this amount tremendously creating way for water pollution. Over exploitation of ground water also disturbs the equilibrium of aquifer from where it is obtained. Even today more than half of the World's population depends on ground water for survival [1]. Ground water is particularly important as it accounts for about $88 \%$ safe drinking water in rural areas where population is widely dispersed and the infrastructure needed for treatment and transportation of surface water does not exist [2]. Due to availability of space and other natural resources industries are mainly located in rural areas. Industrial effluents containing heavy metals pose a threat to the ecosystem [3]. The adverse effects on groundwater quality are burden of the population pressure, unplanned urbanization, unrestricted exploration, unintentionally by domestic, agriculture and industrial effluents and dumping of polluted water at inappropriate place increment the infiltration of harmful compounds to the groundwater [4].Variation of groundwater quality in an area is a function of physicochemical parameters that are greatly influenced

Manuscript received April 14, 2014; revised June 15, 2014.

A. H. Kawade is with the Department of Environmental Engineering, Kolhapur Institute of Technology, Kolhapur , Maharashtra, India (e-mail: akankshakawade7@gmail.com).

P. K. Gadhave is with Department of Mechanical Engineering , Maharashtra Institute of Technology, Pune, Maharashtra, India (e-mail: priyankag_7@yahoo.com). by geological formations and anthropogenic activities [5].

India is the pioneer in sugar production all over the world. Along with all the effluent discharging industries, sugar mills also play a major role in polluting the water bodies. The sugar industry plays an important role in the economic development of India employing about 45 million people, but the effluents released cause high amount of pollution in both aquatic and terrestrial ecosystems [6]. Sugar industry brings along with it ecological problems associated with water, air and soil pollution. The effluents sometimes percolate through subsoil and reach the ground water table forming contaminated pool. This disturbs the natural ground water quality changing its chemical composition.Chemical contamination of drinking water is a matter of serious concern [7], [8]. Intake of contaminated water has adverse effects on the health and can cause various water borne diseases.

The present study aims at evaluating the water quality parameters of ground water around a Cane sugar industry and comparing them to the standard permissible limits prescribed by the Board of Indian Standards (BIS). The study identifies that the ground water quality has been considerably affected due to the effluents from the sugar industry. Efforts should be taken so that the water quality can be restored and its further deterioration can be prevented.

\section{MATERIALS AND METHODS}

\section{A. Study Area}

For the present study the sugar factory located in the town of Sangamner of Maharashtra state in India (Fig. 1) named SahakarMaharshi Bhausaheb Thorat S.S.K.LTD (Fig. 2), has been taken. Sangamner area is located in the northern part of the Ahmednagar district of Maharashtra State. It lies between $18.36^{\prime} \mathrm{N}$ to $19.1^{\prime} \mathrm{N}$ latitude and $74.1^{\prime} \mathrm{W}$ to $74.56^{\prime} \mathrm{W}$ longitude with the population of about 61,958 according to the 2011 census.

\section{B. Procedure}

As the groundwater composition is likely to vary from place to place and also with the depth of the tube well, hence eight samples were collected from tube wells which differed from each other in their depths and the water table depths as mentioned in Table I. All the sites were located within the radius of $1 \mathrm{Km}$ around the factory.

Samples were collected in pre-cleaned Polyethylene bottles. 2 litre samples were collected from each site. The collected samples were brought to the laboratory and were analysed on the same day within 24 hours of collection for $\mathrm{pH}$, chlorine content, potassium $(\mathrm{K}), \quad \operatorname{sodium}(\mathrm{Na})$, 
magnesium $(\mathrm{Mg})$, calcium $(\mathrm{Ca})$, iron $(\mathrm{Fe})$, Biochemical Oxygen Demand (BOD), Chemical Oxygen Demand (COD), Zinc (Zn), Dissolved Oxygen (DO), Total Dissolved Solids (TDS) according to the IS standards [9].

IS standards for respective water quality parameter are listed in Table II. The results obtained were properly tabulated and compared with the normal expected values for drinking water expected. The statistical data was analysed using Microsoft excel.

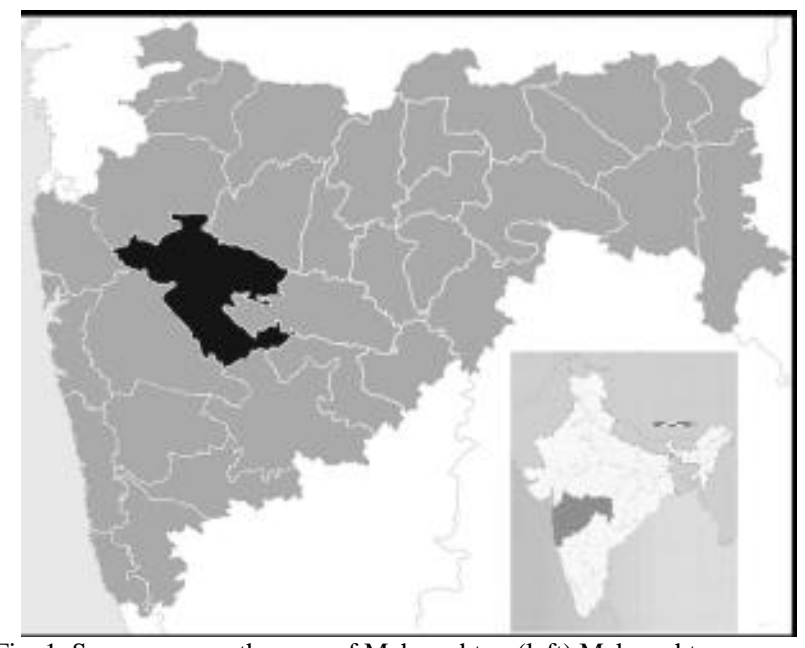

Fig. 1. Sangamner on the map of Maharashtra, (left) Maharashtra as a part of India.

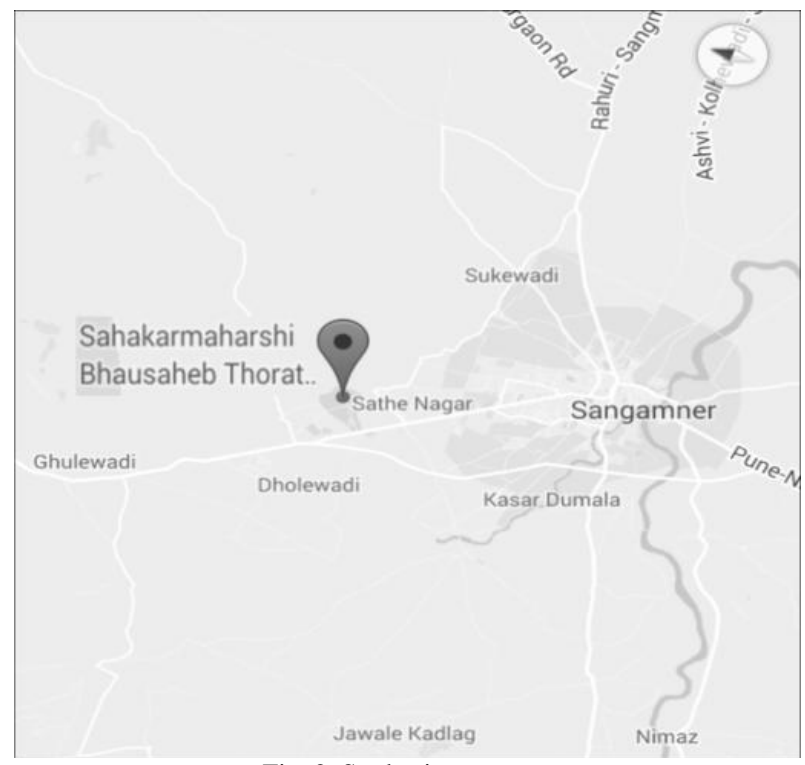

Fig. 2. Study site on map.

TABLE I: THE DEPTHS AND THE WATER TABLE DEPTHS OF THE BORE WELLS SELECTED

\begin{tabular}{|c|c|c|}
\hline Sample & $\begin{array}{c}\text { Depth } \\
\text { (feet) }\end{array}$ & $\begin{array}{c}\text { Water Table } \\
\text { (feet) }\end{array}$ \\
\hline W1 & 250 & 150 \\
\hline W2 & 220 & 120 \\
\hline W3 & 150 & 100 \\
\hline W4 & 75 & 50 \\
\hline W5 & 70 & 35 \\
\hline W6 & 50 & 35 \\
\hline W7 & 40 & 25 \\
\hline W8 & 35 & 22 \\
\hline
\end{tabular}

TABLE II: THE IS STANDARD FOR THE PARAMETERS ANALYZED

\begin{tabular}{|c|c|}
\hline Parameter & IS Standard \\
\hline $\mathrm{pH}$ & IS 3025 P-11:1983 \\
\hline Chloride & IS 3025 P-11:1983 \\
\hline Nitrate & IS 3025 P-11:1983 \\
\hline $\mathrm{K}$ & A.A.S. \\
\hline $\mathrm{Na}$ & A.A.S. \\
\hline $\mathrm{Mg}$ & A.A.S. \\
\hline $\mathrm{Ca}$ & A.A.S. \\
\hline $\mathrm{Fe}$ & A.A.S. \\
\hline $\mathrm{BOD}$ & IS 3025 P-11:1983 \\
\hline $\mathrm{COD}$ & IS 3025 P-11:1983 \\
\hline Zn & A.A.S. \\
\hline DO & IS 3025 P-11:1983 \\
\hline TDS & IS 3025 P-11:1983 \\
\hline
\end{tabular}

\section{RESULTS}

The obtained data was analysed by using Microsoft excel. The mean values of the individual parameters were calculated and are shown in Table III. Table III also displays the normal permissible values of the water quality parameters as mentioned by the BIS standards [9]. BIS standards are the safety standards as prescribed by the government for potable drinking water. The water quality of collected samples was compared with the expected quality and the number of the samples whose water quality parameter's value lies within the permissible limit and of those which exceeds the permissible limit is denoted by Table IV.

TABLE III: MEAN AND PERMisSIBLE VALUES OF THE WATER QUALITY PARAMETERS

\begin{tabular}{|c|c|c|c|}
\hline $\begin{array}{c}\text { Sr. } \\
\text { no. }\end{array}$ & Parameter & $\begin{array}{c}\text { Permissible } \\
\text { value }\end{array}$ & $\begin{array}{c}\text { Mean value } \\
\text { obtained }\end{array}$ \\
\hline 1 & $\mathrm{pH}$ & $6.5-8.5$ & 6.835 \\
\hline 2 & $\mathrm{BOD}(\mathrm{mg} / \mathrm{L})$ & 6 & 42.5 \\
\hline 3 & $\mathrm{COD}(\mathrm{mg} / \mathrm{L})$ & 10 & 92.375 \\
\hline 4 & $\mathrm{DO}(\mathrm{mg} / \mathrm{L})$ & 6 & 4.6875 \\
\hline 5 & $\mathrm{TDS}(\mathrm{mg} / \mathrm{L})$ & $500-2000$ & 1906.75 \\
\hline 6 & $\mathrm{Cl}(\mathrm{mg} / \mathrm{L})$ & $250-1000$ & 522 \\
\hline 7 & $\mathrm{~K}(\mathrm{mg} / \mathrm{L})$ & 10 & 1.962755 \\
\hline 8 & $\mathrm{Na}(\mathrm{mg} / \mathrm{L})$ & 200 & 726.35 \\
\hline 9 & $\mathrm{Mg}(\mathrm{mg} / \mathrm{L})$ & $30-100$ & 323.725 \\
\hline 10 & $\mathrm{Ca}(\mathrm{mg} / \mathrm{L})$ & $75-200$ & 498.2575 \\
\hline 11 & $\mathrm{Fe}(\mathrm{mg} / \mathrm{L})$ & $0.6-1.2$ & $<1$ \\
\hline 12 & $\mathrm{Zn}(\mathrm{mg} / \mathrm{L})$ & 5 & 0.01525 \\
\hline
\end{tabular}

The $\mathrm{pH}$ values of all the samples were well within the permissible limits for drinking water. The biochemical and chemical oxygen demand of potable water according to the BIS standards is expected to be below $6 \mathrm{mg} / \mathrm{L}$ and $10 \mathrm{mg} / \mathrm{L}$ respectively but the actual observed values were very high and averaged at $42.5 \mathrm{mg} / \mathrm{L}$ and $92.325 \mathrm{mg} / \mathrm{L}$ respectively 
indicating large amount of organic and chemical contamination. The dissolved oxygen levels of potable water should lie above $6 \mathrm{mg} / \mathrm{L}$ but the study samples displayed a lower range with the mean dissolved oxygen of $4.6875 \mathrm{mg} / \mathrm{L}$. Though the mean total dissolved solids value was in the permissible limits two samples exceeded the limiting values. Generally, the high total dissolved solids cause gastro-intestinal irritation to the human beings, but the prolonged intake of water with the higher total dissolved solids can cause kidney stones and heart diseases [10].

TABLE IV: PARAMETERS LYING IN THE PERMISSIBLE LIMITS OR EXCEEDING PERMISSIBLE LIMITS

\begin{tabular}{|l|l|l|l|}
\hline Sr. no. & Parameter & $\begin{array}{l}\text { samples within } \\
\text { permissible } \\
\text { limits }\end{array}$ & $\begin{array}{l}\text { samples } \\
\text { exceeding } \\
\text { permissible } \\
\text { limits }\end{array}$ \\
\hline 1 & $\mathrm{pH}$ & All samples & -- \\
\hline 2 & $\mathrm{BOD}(\mathrm{mg} / \mathrm{L})$ & -- & All samples \\
\hline 3 & $\mathrm{COD}(\mathrm{mg} / \mathrm{L})$ & -- & All samples \\
\hline 4 & $\mathrm{DO}(\mathrm{mg} / \mathrm{L})$ & -- & All samples \\
\hline 5 & $\mathrm{TDS}(\mathrm{mg} / \mathrm{L})$ & $\begin{array}{l}\text { W3,W4,W5,W6 } \\
\text { W7,W8 }\end{array}$ & W1,W2 \\
\hline 6 & $\mathrm{Cl}(\mathrm{mg} / \mathrm{L})$ & All samples & -- \\
\hline 7 & $\mathrm{~K}(\mathrm{mg} / \mathrm{L})$ & All samples & -- \\
\hline 8 & $\mathrm{Na} \mathrm{(mg/L)}$ & -- & All samples \\
\hline 9 & $\mathrm{Mg}(\mathrm{mg} / \mathrm{L})$ & -- & All samples \\
\hline 10 & $\mathrm{Ca} \mathrm{(mg/L)}$ & W7 & $\begin{array}{l}\text { W1,W2,W3,W4, } \\
\text { W5,W6,W8 }\end{array}$ \\
\hline 11 & Fe (mg/L) & All samples & -- \\
\hline 12 & Zn (mg/L) & All samples & -- \\
\hline & & &
\end{tabular}

All the samples showed acceptable amounts of potassium, chlorides, iron and zinc. The water samples displayed mean of the sodium and magnesium content to be very high with the mean values $726.35 \mathrm{mg} / \mathrm{L}$ and $323.725 \mathrm{mg} / \mathrm{L}$ individually. The excess consumption of sodium has been recognized as risk factor in hypertension [11]. Magnesium is an essential ion for functioning of cells in enzyme activation, but at higher concentration, it is considered as laxative agent [12], while deficiency may cause structural and functional changes in human beings. Except sample W7 all the water samples exceeded the amount of calcium content. The excess intake of calcium may cause kidney stones [13] or insulin resistance [14] and that of magnesium may lead to bowel dysfunction [14].

\section{CONCLUSION}

The results of the study display the fact that the influx of effluents from cane sugar factory has rendered the ground water around it unfit for drinking. Even though the parameters like $\mathrm{pH}$, Total dissolved solids, chloride content, potassium, iron and zinc are well within the limits the superfluous values of sodium, magnesium, biochemical oxygen demand and chemical oxygen demand combined with deficient dissolved oxygen levels show the considerably degraded water quality. This degraded water if used for drinking purposes can pose a major to the health of the people consuming it. Also if this deterioration of water goes unchecked it will render the water table and the soil in contact with it completely unfit for consumption and cultivation.

Large population of India uses ground water for drinking purposes without any treatment and hence possesses potential health risk. Since the fact that health of many is at stake it is the need of the hour to ensure that proper measures are taken to avoid further deterioration of water and that people get potable water to drink. In order to achieve sustainable development in the future, the ground water pollution around the industry must be checked and probable measures must also be evaluated.

\section{REMEDial MEASURES}

Certain measures can be implemented to abate this pollution. They are stated as follows:

1) Every sugar factory should have a good ETP plant and the effluents from the factory shouldn't be let out on the land without prior treatment.

2) The government should formulate strict laws regarding the disposal of the effluents and should ensure their implementation.

3) Awareness among people regarding environmental issues and their impact on health should be increased.

4) Water treatment plants should be installed nearby sugar industries and the people living near to the factory should be supplied ground water for drinking necessarily after proper treatment.

5) Time to time assessment of the ground water near to a sugar factory for its quality should be done.

\section{REFERENCES}

[1] R. C. Sheth and B. M. Kalshetty, "Water quality assessment of ground water resources around sugar factory of Jamkhandi town, Bagalkot,Karnataka," International Journal of Applied Biology and Pharmaceutical Technology, vol. 1, no. 2, Jan. 2011.

[2] P. Alexandra,"Evaluation of ground water quality of Mobi town in Adawana state, Nigeria," African Journal of Biotechnology, vol. 7, no. 11, pp. 1712-1715, Jun. 2008.

[3] A. Amathussalam, M. N. Abusbacker, and N. J. Jayabal, "Physicochemical parameters and concentration of heavy metals in sugar industry," Indian Pollution Conference Proceedings, vol. 13, pp. 118119, 2002.

[4] K. P. Sandeep and S. Tiwari, "Physico-chemical analysis of ground water of selected area of Ghazipur city-A case study," Nature and Science, vol. 7, no. 1, 2009.

[5] R. K. S. Vennila, "Hydrochemical analysis and evaluation of groundwater quality in and around Hosur, Krishnagiri district, Tamil Nadu, India," International Journal of Research in Chemistry and Environment, vol. 2, pp. 112-113, July 2012.

[6] P. M. Ayyasamy, R. Yasodha, S. Rajakumar, P. Lakshmanaperumalsamy, and S. R. Lee, "Impact of sugar factory effluent on the growth and biochemical characteristics of terrestrial and aquatic plants," Bull. Environ. Contam .Toxicol., vol. 81, pp. 449454, 2008.

[7] S. S. Kakati, "Assessment of major anion level of water sources used for domestic purposes in the tribal villages of Dhakuakhana sub division of Lakhimpur district Assam," International Journal of Chemical Science, vol. 8, no. 3, pp. 1863-1870, 2009.

[8] K. Brindha, L. Elango, and V. G. Rajesh, "Occurrence of chromium and copper around tanneries in chrompet area of Tamil Nadu, India," Indian J. Environmental Protection, vol. 30, no. 10, pp. 818-822, 2010 .

[9] Drinking Water - Specification, Indian Standard 3025-1983, 2002.

[10] V. K. Garg, S. Suthar, S. Singh, A. Sheoran, M. Garima, and S. Jai, "Drinking water quality in villages of southwestern Haryana, India: assessing human health risks associated with hydrochemistry," Environ Geol., vol. 58, pp. 1329-1340, 2009. 
[11] WHO, "Sodium, chlorides and conductivity in drinking water: Report on a WHO working Group," Copenhegan, Euro Reports and Studies, no. $2,1979$.

[12] V. K. Garg, S. Suthar, S. Singh, A. Sheoran, M. Garima, and S. Jai, "Drinking water quality in villages of southwestern Haryana, India: assessing human health risks associated with hydrochemistry," Environ Geol., vol. 58, pp. 1329-1340, 2009.

[13] L. J. Leurs et al., "Relationship between tap water hardness, magnesium, and calcium concentration and mortality due to ischemic heart disease or stroke in the Netherlands," Environmental Health Perspectives, vol. 118, no. 3, pp. 414-420, 2010.

[14] WHO. (2009). Calcium and magnesium in drinking-water: public health significance. Geneva, World Health Organization. [Online] Available: http://whqlibdoc.who.int/publications/2009/9789241563550_eng.pdf

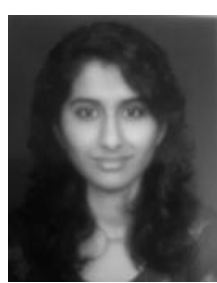

Akanksha Haribhau Kawade was born on 29 September 1992 in Nasik, Maharashtra, India. Currently she is studying in the third year of bachelor's degree in environmental engineering from Kolhapur Institute of Technology from Kolhapur university, Maharashtra, India.

She has participated in training programs like GIS(global positioning systems), National level student political conclave named Indian Student parliament and conference like Indian Science Congress.

Ms. Akanksha H. Kawade is also a student member of the Indian Society of Technical Education, New Delhi, India.

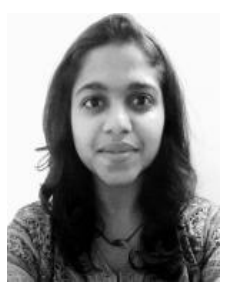

Priyanka K. Gadhave was born on 13 July, 1993 in the Ahmednagar, Maharashtra, India. Currently she is studying in the third year of the bachelors' degree in environmental engineering from Maharashtra Institute of Technology from Pune University, Maharashtra India.

She holds the position as director at MauliSchool and Workshop for mentally retarded children, Ranjangaon, Ahmednagar, Mahrashtra, India. She has published two research papers on material sciences and Nanotechnology in the year 2013 in World Congress on Engineering by IAENG. She has addressed a national level political conclave named Indian Student parliament.

Ms. Priyanka is also a member of SAE: The Engineering Society for Advancing Mobility Land Sea Air and Space. 

Clean Energy 
